\title{
English Language Teachers' Perceptions and Practices on Learner Autonomy in Nepalese Context
}

\author{
Prakash Bhattarai \\ Tribhuvan University, Kathmandu, Nepal \\ prakash.766671@gse.tu.edu.np
}

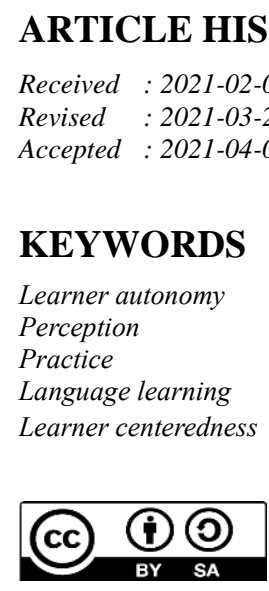

\begin{abstract}
Learner autonomy is the ability and responsibility of learners to take control of their learning. Motivation, the chance to work independently and/ or collaboratively, access to the internet and library, and challenging tasks promote learner autonomy. This study explores English language teachers' perceptions and practices on learner autonomy and finds the difference in the perceptions and practices by their sex, level, qualification, and type of school they teach. One hundred thirty-three (133) teachers teaching at Tulsipur Sub-metropolitan Dang, Nepal, were selected using the fishbowl technique. Data drawn with the questionnaire's help were analysed via univariate (frequency, percentage, and median) and bivariate (t-test and Cohen's d) analysis. From the analyses, it was found that English language teachers teaching at different levels are aware of the what, why, and how of learner autonomy, and they promote learner autonomy by engaging and encouraging students to be involved in the tasks which promote learner autonomy. Perceptions on learner autonomy do not differ by their sex, level, qualification, and type of school they teach. Likewise, practices on learner autonomy also do not differ by the sex and level of the teachers, but their practices differ by the type of school where they teach and their qualification.
\end{abstract}

\section{Introduction}

Learner autonomy is the capacity of learners to be autonomous and responsible for one is one learning. Holec (1981 as cited in Xhaferi \& Xhaferi, 2011) defines learner autonomy as "the ability to take charge of one's learning. " Similarly defining learning autonomy, Little (1995) states that learner autonomy is "essentially a matter of the learner's psychological relation to the process and content of learning--a capacity for detachment, critical reflection, decisionmaking, and independent action. "It is a learner who is responsible for his/her learning. The learner should direct one's learning taking the decisions which are related to his/her learning. In this line, Dickinson (1987, p. 11) believes that learner autonomy is a "situation in which the learner is responsible for all decisions concerned with his or her learning and implementing those decisions." The fundamental topics in foreign language education are learner autonomy and learner responsibility (Yagcioglu, 2015). Being responsible for all of the decisions concerned with learning means "determining the objectives, defining the contents and progressions, selecting methods and techniques to be used, monitoring the procedure of acquisition and evaluating what has been acquired" (Holec, 1981 as cited in Borg \& Al-Busaidi, 2012).

Benson and Voller (1997, p. 2) hold that autonomy consists at least five phases, "for situations in which learners study entirely on their own; for a set of skills which can be learned and applied in self-directed learning; for an inborn capacity which is suppressed by institutional education; for the exercise of learners' responsibility for their learning; for the right of learners to determine the direction of their learning." This shows that learners themselves should be responsible for taking charge of every learning aspect to be autonomous. Najeeb (2013) writes, "Taking charge of one's learning is a prerequisite of learning and learning itself is impossible without the learner taking charge" (p. 1239). It suggests that learner autonomy is based on the idea that if students are involved in decisionmaking processes regarding their language learning, they are more responsible and enthusiastic about their learning. Such enthusiasm leads them to be successful language learners. In other words, if students take charge of their learning, they learn the language more efficiently and faster than the situation where they are forced to do it. 
Recent developments in the field of language teaching and learning have modified teaching-learning styles. This has made teachers have a paradigm shift in second language teaching and learning from traditional methods to modern ones. In a traditional classroombased on teacher-centeredness, a teacher is an authority; as a source of knowledge. The teacher makes decisions on what to teach and when. In other words, students have no or minor role in deciding what to learn and how to learn. A teacher is considered authoritative, whereas learners are passive listeners who are supposed to listen attentively to what they have been poured into. Learner autonomy, on the other hand, is based on the principle of learner-centeredness. The modern approaches and methods of language teaching in general and English language teaching, in particular, put learners in the centre of teaching-learning activities. They focus that learners cannot learn the language until and unless they become active in their learning.

To make learners active and take charge of their learner, the teacher's role should be facilitator and/or counsellor. The teacher guides the students to accept responsibility for their learning, guides them to be reflectively engaged in planning, monitoring, and evaluating their learning (Asmari, 2013). This statement shows that the teacher has to guide the students to accept the charge of their learning. The teacher has to help learners learn how to learn, equip them with the means necessary to self-direct their learning, raise the consciousness of good language learners about the learning, and make the strategies explicit and systematic so that they are available to improve the language learning abilities of other learners as well (Kumaravadivelu, 1994).

In this line, Little (1995) states, "It is often argued that the pursuit of learner autonomy requires a shift in the role of the teacher from a purveyor of information to a facilitator of learning and manager of learning resources." The teacher's role is to facilitate learners to take decisions on their learning, motivate them, provide feedback and manage resources. The teacher of autonomous leaner(s) has these characteristics: is aware of her influence on the learning process, understands pedagogy, is skilled in management (Camilleri, 1999 as cited in Joshi, 2011).

The teacher can play a crucial role in promoting learner autonomy in the classroom and outside the classroom. In the classroom, a teacher can promote learner autonomy by providing such tasks, which promote learner autonomy and motiving them to accomplish the tasks on their own or in collaboration with their friends. A teacher can guide or facilitate the learners where necessary. A teacher can encourage the students to use different self-access resources like library/internet to promote learner autonomy outside the classroom. Learner autonomy brings a change in teachers' roles from authoritative to the facilitator, counsellor and manager, where the responsibility of teachers is to create conditions for learners where they can work on their own, reflect on their progress and self-evaluate their work (Neupane, 2010). In one sentence, what can be said is a teacher has an essential role in promoting learner autonomy both in and outside the classroom.

The perceptions and practices of teachers on learner autonomy vary from teachers to teachers. Some teachers view that learner autonomy should be/can be promoted, providing opportunities to the learners to take charge of their learning. The teachers who favour learner autonomy opine that students can do a lot on their own if they are facilitated or guided. The teacher's task is to provide learners with the opportunities and resources which promote their autonomy. On the other hand, some teachers opine that students cannot learn independently since they are reluctant to their learning. Learner autonomy, as discussed earlier, is the ability of learners to take charge of their learning where the students take every decision regarding their learning which may be pretty impossible. The students who are used to learning with the help of their teachers may find it challenging to learn independently.

Various studies have been conducted on teachers' perceptions of learner autonomy. Balçıkanlı (2010) examined the views of 112 student teachers of English in Turkey. The results suggested that the student teachers were positive about involving students in decisions about a wide range of classroom activities. Similarly, Joshi (2011) conducted a study using a mixed methodological design to determine learner perceptions and teacher beliefs about learner autonomy in language learning. He found that the learners make a good practice of autonomous activities, and the teachers have also suggested the learners be autonomous. The teachers, as well as the learners, were found highly positive towards autonomous learning. In a similar vein, Reinders and Lazaro (2011) interviewed 46 teachers working in self-access centres and saw autonomy as equality and respect between teachers and learners and empowerment. The students were not seen to value or be ready for autonomy. They also found some institutional constraints on promoting autonomy.

Nakata (2011) identified a gap between teachers' positive views about learner autonomy and their reported classroom practices in encouraging learners to be autonomous. Borg and Al-Busaidi (2012) studied the beliefs and reported practices regarding learner autonomy of 61 teachers of English. The findings highlighted a range of ways teachers conceptualised learner autonomy, though it was commonly seen in 
terms of independent and individual learning strategies. The study also shed light on both teachers' positive theoretical dispositions to learner autonomy and their less optimistic views about the feasibility of promoting it in practice. A survey among 60 teachers conducted by Asmari (2013) collected the opinion of teachers regarding the practices and prospects of learner autonomy in their classrooms. The study's findings stressed that it is crucial to provide learner training together with the studies and make it an integral part of the teaching process to help learners become autonomous.

Borg and Alshumaimeri (2019) examined the beliefs, practices, and constraints related to learner autonomy reported by 359 teachers (mainly expatriate) working on an English Preparatory Year Programme (PYP) at a university in Saudi Arabia. The teachers believed that promoting learner autonomy was a desirable goal and described how they tried to achieve this goal in their teaching. Most were, however, less optimistic about the feasibility of promoting learner autonomy and explained this about curricular, societal and, above all, learner factors (such as lack of motivation and independence and low proficiency in English).

These studies have highlighted the role of teachers in promoting learner autonomy and their perceptions of it. They have pointed out that teachers have a crucial role in promoting learner autonomy. Despite their essential roles, they have different perceptions and practices on it. Moreover, these studies have revealed the higher level /tertiary teachers' perceptions and reported practices on learner autonomy. However, these studies have not found the difference in the perceptions and practices by sex, level, type of school and qualification of English language teachers.

Keeping these things in mind, this study aims to explore English language teachers' perceptions and practices on learner autonomy and find the difference in the teachers' perceptions and practices by sex, level, type of school, and qualification. This study tries to answer a) Are English language teachers aware of learner autonomy?, b) How do they perceive it?, c) How do teachers practice/promote learner autonomy in their classroom and d) Is there is any difference in the perceptions and practices by sex, level, qualification of teachers and type of the school they teach.

\section{Method}

This quantitative study's population was English language teachers teaching at the primary and secondary level in both private and community schools at Tulsipur Sub-metropolitan, Dang, Nepal. After calculating the sample size, 133 teachers were selected randomly using the fishbowl technique. The selected teachers were sent a questionnaire (which was in Microsoft Form) via Facebook messenger. The questionnaire was divided into three sections: background information, perceptions on learner autonomy, and learner autonomy. The background information section was to know the respondents' background like sex, level, type of school where they teach and qualification. Likewise, perceptions on learner autonomy section, which had ten statements, explored the teachers' perception on learner autonomy and practices on learner autonomy section, which had eleven statements, was to explore the teachers' practices on learner autonomy.

After receiving the data from the teachers, teachers' perceptions and practices on learner autonomy were analysed in univariate analysis: frequency count, percentage and median, whereas bivariate analysis ( $t$ test) was calculated to find the difference in perceptions and practices on learner autonomy (dependent variables) by sex, level, type of school and qualification of the respondents (independent variables). Statistical Package for Social Science (SPSS) was used for both the analysis-- univariate and bivariate analysis (t-test). Moreover, to find out the effect of the difference, Cohen's d was calculated manually.

\section{Findings}

This section deals with English language teachers' perceptions and practices on learner autonomy and the difference in perceptions and practices by sex, level, type of school, and teacher qualification.

\subsection{English Language Teachers' Perceptions on Learner Autonomy}

Different ten statements related to learner autonomy were given to the respondents to explore their perceptions of learner autonomy. The respondents had to select one option (strongly agree, agree, unsure, disagree and strongly disagree) for each statement. Table 1 shows the responses made by the respondents summarised under their frequency, percentage and median. 
Table 3.1. Teachers' Perceptions on Learner Autonomy

\begin{tabular}{|c|c|c|c|c|c|c|c|c|c|c|c|c|}
\hline \multirow{3}{*}{ No. } & \multirow{3}{*}{ Statements } & \multicolumn{10}{|c|}{ Responses } & \multirow{3}{*}{ Median } \\
\hline & & \multicolumn{2}{|c|}{$\begin{array}{l}\text { Strongly } \\
\text { agree }(5)\end{array}$} & \multicolumn{2}{|c|}{ Agree (4) } & \multicolumn{2}{|c|}{$\begin{array}{l}\text { Unsure } \\
\text { (3) }\end{array}$} & \multicolumn{2}{|c|}{$\begin{array}{l}\text { Disagree } \\
\quad(2)\end{array}$} & \multicolumn{2}{|c|}{$\begin{array}{c}\text { Strongly } \\
\text { disagree(1) }\end{array}$} & \\
\hline & & $\mathrm{N}$ & $\%$ & $\mathrm{~N}$ & $\%$ & $\mathrm{~N}$ & $\%$ & $\mathrm{~N}$ & $\%$ & $\mathrm{~N}$ & $\%$ & \\
\hline 1. & $\begin{array}{l}\text { I have good knowledge of learner } \\
\text { autonomy. }\end{array}$ & 28 & 21.1 & 95 & 71.4 & 10 & 7.5 & - & - & - & - & 4 \\
\hline 2. & $\begin{array}{l}\text { Learner autonomy means learners can } \\
\text { make choices on how they learn. }\end{array}$ & 40 & 30.1 & 84 & 63.2 & 8 & 6.0 & 1 & 0.8 & - & - & 4 \\
\hline 3. & $\begin{array}{l}\text { The teacher has an important role in } \\
\text { supporting learner autonomy. }\end{array}$ & 47 & 35.3 & 81 & 60.9 & 5 & 3.8 & - & - & - & - & 4 \\
\hline 4. & $\begin{array}{l}\text { Learner autonomy has a positive effect } \\
\text { on language learning. }\end{array}$ & 50 & 37.6 & 81 & 60.9 & 1 & .8 & 1 & 0.8 & - & - & 4 \\
\hline 5. & $\begin{array}{l}\text { Motivation plays a vital role in } \\
\text { promoting learner autonomy. }\end{array}$ & 67 & 50.4 & 59 & 44.4 & 7 & 5.3 & - & - & - & - & 5 \\
\hline 6. & $\begin{array}{l}\text { Self-access centres/ resources like the } \\
\text { library, internet promote learner } \\
\text { autonomy. }\end{array}$ & 64 & 48.1 & 60 & 45.1 & 9 & 6.8 & - & - & - & - & 4 \\
\hline 7. & $\begin{array}{l}\text { Learner autonomy is promoted through } \\
\text { regular opportunities for completing } \\
\text { different tasks independently. }\end{array}$ & 38 & 28.6 & 91 & 68.4 & 4 & 3 & - & - & - & - & 4 \\
\hline 8. & $\begin{array}{l}\text { Cooperation and collaboration among } \\
\text { the students promote learner autonomy. }\end{array}$ & 59 & 44.4 & 66 & 49.6 & 8 & 6.0 & - & - & - & - & 4 \\
\hline 9. & $\begin{array}{l}\text { The tasks that are done outside the } \\
\text { classroom too promote learner } \\
\text { autonomy. }\end{array}$ & 29 & 21.8 & 94 & 70.7 & 9 & 6.8 & 1 & 0.8 & - & - & 4 \\
\hline 10. & Students cannot learn without a teacher. & 2 & 1.5 & 7 & 5.3 & 8 & 6.0 & 84 & 63.2 & 32 & 24.1 & 2 \\
\hline
\end{tabular}

Table 3.1 reveals that most respondents, 95 $(71.4 \%)$, agreed, and $28(21.1 \%)$ respondents strongly agreed that they have good knowledge of learner autonomy. The median (4) indicated that teachers have good knowledge of learner autonomy. Similarly, most of the respondents, $84(63.2 \%)$ agreed and (40) $30.1 \%$ of respondents strongly agreed that learner autonomy means learners can choose how they learn. This data and median (4) showed the teachers perceive that learners can choose how they learn to be autonomous. Among the respondents, $47(35.3 \%)$ respondents marked that they strongly agree, $81(60.9 \%)$ marked on agree. The median value (4) displayed that teacher has a vital role in supporting learner autonomy. In response to the 4th statement, $50(37.6 \%)$ respondents strongly agreed, and $81(60.9 \%)$ agreed with the statement, and the median value is 4 . It indicated that learner autonomy has a positive effect on language learning.

In a similar vein, it was found that motivation plays a vital role in promoting learner autonomy since 67 $(50.4 \%)$ respondents strongly agreed that 59 (44.4\%) agreed on promoting learner autonomy. The median value that is five also indicated this finding. Likewise, among the respondents, 64 ( $48.1 \%)$ strongly agreed, and $60(45.1 \%)$ agreed regarding the role of self-access centres/ resources, and the median value is four which indicated that self-access centres/resources like the library, internet promote learner autonomy. It was found that learner autonomy is promoted through regular opportunities for completing different tasks independently because a majority of the respondents, i.e. $91(68.4 \%)$, agreed on the statement 'learner autonomy is promoted through regular opportunities for completing different tasks independently'. This result is indicated by median value (4) too.

Similarly, 59 (44.4\%) respondents strongly agreed, $66(49.6 \%)$ agreed, and the median value is four which showed that cooperation and collaboration among the students promote learner autonomy. A majority of the respondents, i.e. 94 (70.7\%) respondents agreed on the 9th statement, and the median is four, so the researcher concluded that the tasks that are done outside the 
classroom promote learner autonomy. In a similar vein, $84(63.2 \%)$ disagreed, $32(24.1 \%)$ strongly disagreed, whereas $8(6.0 \%)$ remained unsure, $7(5.3 \%)$ agreed, and only $2(1.5 \%)$ strongly agreed with the statement 'Students cannot learn without a teachers' and the median value is 2 . This data indicated that students could learn without a teacher.

\subsection{English Language Teachers' Practices on Learner Autonomy}

Different statements related to learner autonomy were given to the respondents to investigate their practices on learner autonomy. The respondents had to select one option (always, sometimes, never) for each statement revealing their practices on learner autonomy. Table 3.2 shows the responses made by the respondents summarised under their frequency, percentage and median.

Table 3.2. Teachers' Practices on Learner Autonomy

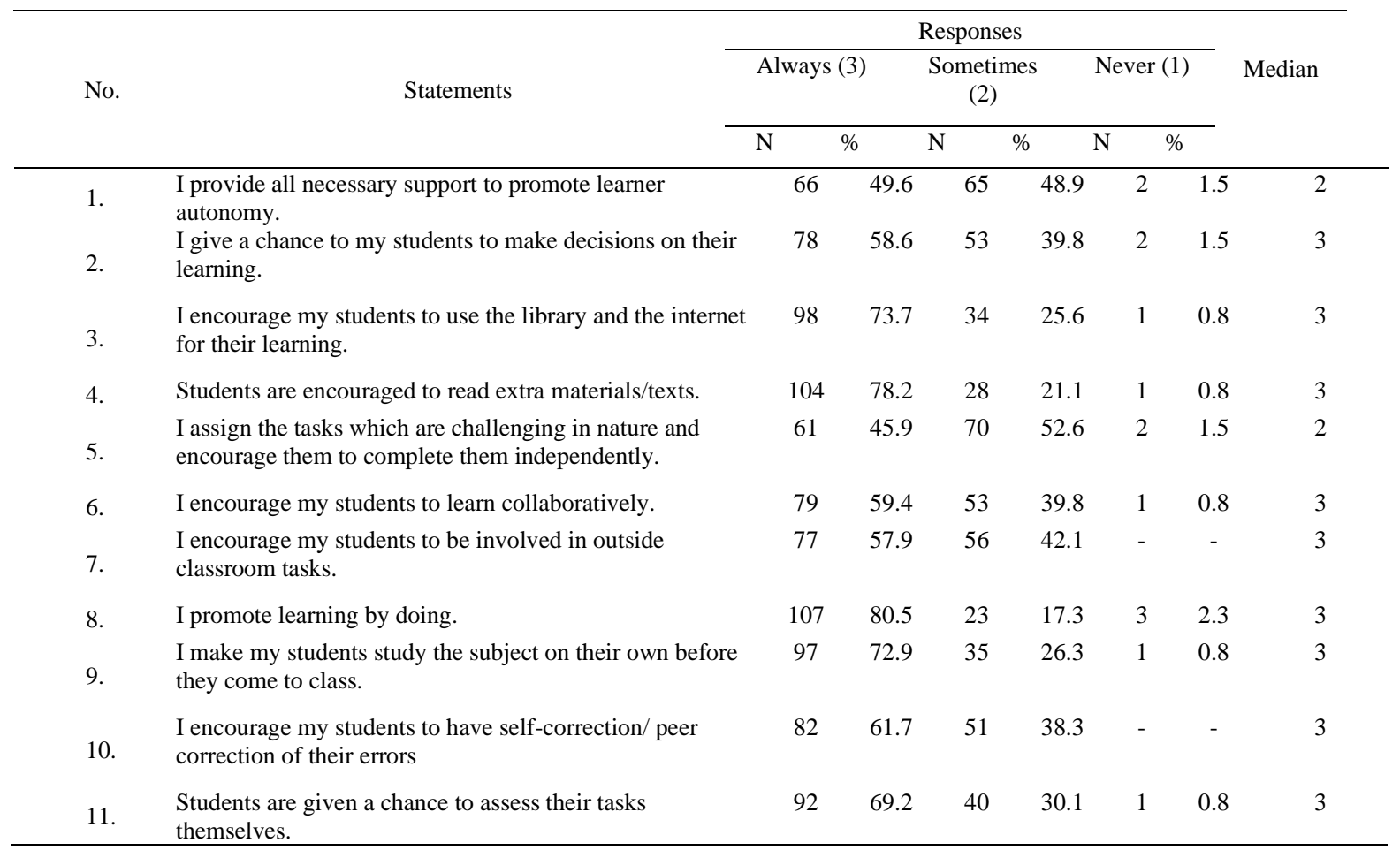

Table 3.2 shows that $66(49.6 \%)$ respondents marked that they always provide the necessary support to promote learner autonomy, and $65(48.9 \%)$ marked in sometimes. The median (2) indicated that teachers sometimes provide all necessary support to promote learner autonomy. Similarly, 78(58.6\%) marked always, and $53(39.8 \%)$ sometimes marked in the second statement. A majority of the respondents marked 'always', the median (3) suggested that teachers always give their students a chance to make decisions on their learning. It was found that teachers always encourage their students to use the library and internet for their learning with the median value's help (3). Likewise, $104(78.2 \%)$ respondents marked that students are always encouraged to read extra materials/texts. In response to the 5th statement, 61 (45.9\%) respondents marked 'always', and 70 (53.6\%) marked 'sometimes'. This data and median (2) indicated that teachers sometimes assign challenging tasks to the students and encourage them to complete independently.

Students are always encouraged to learn collaboratively, indicated by the data- 79 (59.4\%) respondents marked 'always' and median (3). It was found that teachers always encourage students to be involved in outside classroom tasks since most of the respondents, 77 (57.9\%), marked 'always' and the median is 3 . In a similar vein, most of the respondents, i.e. 107 (80.5), marked that they always promote learning by doing. The median value (4) of this data revealed that teachers promote the principle of learning by doing to promote learner autonomy. A majority of the respondents marked that they always make their students study the subject matter on their own before they come to class. The median (3) showed that teachers always make their students study independently before they come to class. In terms of error correction, teachers always encourage their 
students to have self/peer correction of their errors, which helps promote learner autonomy. This finding is made based on the data, i.e. $82(61.7 \%)$ respondents always do the task, 51 (38.3\%) do it sometimes, and the median is 3 . In the same way, in the statement 'students are given a chance to assess their tasks themselves, 92 $(69.2 \%)$ marked that they do it continuously, 40 $(30.1 \%)$ do it sometimes, and only $1(0.8 \%)$ never does it. From this data and median value 3 , it was concluded that students are given a chance to assess their task themselves by the teachers.

\subsection{Difference in Perceptions on Learner Autonomy by Sex, Type of School, Level and Qualification}

This section deals with analysing the differences in perceptions on learner autonomy by the sex, type of school, level and qualification of the English language teachers. T-test was done to determine the statistically significant differences in learner autonomy perceptions between male and female teachers, teachers teaching in private and community school, teachers of primary level and secondary level and teachers having bachelors and masters qualification. Then, the strength of statistical difference was measured by Cohen's $d$. Table 3.3 summarises the value of the t-test and Cohen's d.

Table 3.3 Differences in Perceptions on Learner Autonomy

\begin{tabular}{|c|c|c|c|c|c|c|c|c|}
\hline \multicolumn{2}{|c|}{ Variables } & \multirow{3}{*}{$\begin{array}{l}\mathrm{N} \\
90 \\
43\end{array}$} & \multirow{3}{*}{$\begin{array}{l}\text { Mean } \\
40.62 \\
40.67\end{array}$} & \multirow{3}{*}{$\begin{array}{c}\text { Std. Deviation } \\
2.59 \\
2.44\end{array}$} & \multirow{3}{*}{$\begin{array}{c}\mathrm{T} \\
-0.11\end{array}$} & \multirow{3}{*}{$\begin{array}{c}\text { Df } \\
131\end{array}$} & \multirow{3}{*}{$\begin{array}{l}\text { Sig. }(2 \\
\text { tailed })\end{array}$} & \multirow{3}{*}{$\begin{array}{c}\mathrm{D} \\
0.01 \#\end{array}$} \\
\hline \multirow{2}{*}{$\begin{array}{l}\text { Sex of the } \\
\text { respondents }\end{array}$} & Male & & & & & & & \\
\hline & Female & & & & & & & \\
\hline \multirow{2}{*}{ Type of school } & Private & 37 & 40.22 & 2.28 & \multirow{2}{*}{-1.19} & \multirow{2}{*}{131} & \multirow{2}{*}{$0.23 *$} & \multirow{2}{*}{$0.24 \# \#$} \\
\hline & Community & 96 & 40.80 & 2.62 & & & & \\
\hline \multirow{2}{*}{ Level } & Basic & 49 & 40.35 & 2.23 & \multirow{2}{*}{-1.01} & \multirow{2}{*}{131} & \multirow{2}{*}{$0.31^{*}$} & \multirow{2}{*}{$0.18 \#$} \\
\hline & Secondary & 84 & 40.81 & 2.70 & & & & \\
\hline \multirow{2}{*}{ Qualification } & Bachelor & 46 & 40.52 & 2.02 & \multirow{2}{*}{-0.39} & \multirow{2}{*}{131} & \multirow{2}{*}{$0.70^{*}$} & \multirow{2}{*}{$0.07 \#$} \\
\hline & Masters & 87 & 40.70 & 2.78 & & & & \\
\hline
\end{tabular}

Here, $*=$ no statistically significant \# weak effect \#\# modest effect

Table 3.3 shows that regarding the sex of the respondents, the $\mathrm{t}$-value is -0.11 , degree of freedom (df) is 131 and significance level is 0.19 , which is (p> $0.05)$. It shows no statistically significant difference in perceptions of learner autonomy between male and female teachers. Moreover, the calculated value of Cohen's $d$ is 0.01, which signifies the weak effect in the difference. Here, it can be concluded that the difference in perceptions on learner autonomy between the male and female teachers is weak. Similarly, regarding the type of school, the t-value is -1.19 , degree of freedom (df) is 131 and significance level is 0.23 , which is (p> $0.05)$. It accepts the null hypothesis that there is no statistically significant difference in learner autonomy perceptions between teachers teaching at private schools and community schools. Moreover, the calculated value of Cohen's $d$ is 0.24 , which signifies the modest effect in the difference. Here, it can be concluded that the difference in perceptions on learner autonomy between the teachers teaching at private schools and community schools is modest.

Likewise, regarding the level of teachers, the tvalue is -1.01 , the degree of freedom (df) is 131 , and the significance level is 0.31 , which is $(p>0.05)$. It suggests no statistically significant difference in perceptions of learner autonomy between teachers teaching at the primary and secondary levels. Moreover, the calculated value of Cohen's $d$ is 0.18 , which signifies the weak effect in the difference. Here, it can be concluded that the difference in perceptions on learner autonomy between the teachers teaching at the primary level and secondary level is weak. In a similar vein, regarding the qualification of teachers, the $\mathrm{t}$-value is -0.39 , degree of freedom (df) is 131 and significance level is 0.70 , which is ( $p>0.05$ ). It suggests there is no statistically significant difference in perceptions on learner autonomy between teachers having bachelor's and master's qualifications. Moreover, the calculated value of Cohen's $d$ is 0.07 , which signifies the weak effect in the difference. Here, it can be concluded that the difference in perceptions on learner autonomy between the teachers having bachelor's and master's qualifications is weak.

\subsection{Difference in Practices on Learner Autonomy by Sex, Type of School, Level and Qualification}


This section deals with analysing the differences in practices on learner autonomy by the sex, type of school, level and qualification of the English language teachers. T-test was done to determine the statistically significant differences in learner autonomy practices between male and female teachers, teachers teaching in private and community school, teachers of primary level and secondary level and teachers having bachelors and masters qualification. Then, the strength of statistical difference was measured by Cohen's d. Table 3.4 summarises the value of the t-test and Cohen's d.

Table 3.4 Difference in Practices on Learner Autonomy

\begin{tabular}{|c|c|c|c|c|c|c|c|c|}
\hline \multicolumn{2}{|c|}{ Variables } & $\mathrm{N}$ & Mean & $\begin{array}{c}\text { Std. } \\
\text { Deviation }\end{array}$ & $\mathrm{T}$ & Df & $\begin{array}{l}\text { Sig. (2 } \\
\text { tailed) }\end{array}$ & $\mathrm{D}$ \\
\hline \multirow{2}{*}{$\begin{array}{l}\text { Sex of the } \\
\text { respondents }\end{array}$} & Male & 90 & 28.84 & 2.68 & \multirow{2}{*}{-0.83} & \multirow{2}{*}{131} & \multirow{2}{*}{$0.40 *$} & \multirow{2}{*}{$0.16 \#$} \\
\hline & Female & 43 & 29.23 & 2.12 & & & & \\
\hline \multirow{2}{*}{ Type of school } & Private & 37 & 29.86 & 1.91 & \multirow{2}{*}{2.99} & \multirow{2}{*}{89.71} & \multirow{2}{*}{$0.004 * *$} & \multirow{2}{*}{$0.54 \# \#$} \\
\hline & Community & 96 & 28.62 & 2.64 & & & & \\
\hline \multirow{2}{*}{ Level } & Basic & 49 & 28.77 & 2.56 & \multirow{2}{*}{-0.70} & \multirow{2}{*}{131} & \multirow{2}{*}{$0.50^{*}$} & \multirow{2}{*}{$0.12 \#$} \\
\hline & Secondary & 84 & 29.08 & 2.50 & & & & \\
\hline \multirow{2}{*}{ Qualification } & Bachelor & 46 & 29.96 & 2.36 & \multirow{2}{*}{3.41} & \multirow{2}{*}{131} & \multirow{2}{*}{$0.001 * *$} & \multirow{2}{*}{$0.62 \# \#$} \\
\hline & Masters & 87 & 28.45 & 2.45 & & & & \\
\hline
\end{tabular}

Here, $*=$ no statistically significant, $* *=$ statistically significant, \#= weak effect, \#\#= moderate effect

Table 3.4 shows that regarding the sex of the respondents, the $\mathrm{t}$-value is -0.83 , degree of freedom (df) is 131 and significance level is 0.40 , which is (p> $0.05)$. It shows no statistically significant difference in practices on learner autonomy between male and female teachers. Moreover, the calculated value of Cohen's d is 0.16 , which signifies the weak effect in the difference. Here, it can be concluded that the difference in practices on learner autonomy between the male and female teachers is weak. Similarly, regarding the type of school, the t-value is 2.99 , degree of freedom (df) is 89.71 and significance level is 0.004 , which is $(\mathrm{p}<$ 0.05 ). It shows a statistically significant difference in practices on learner autonomy between teachers teaching at private schools and community schools. Moreover, the calculated value of Cohen's $d$ is 0.54 , which signifies the moderate effect in the difference. Here, it can be concluded that the difference in practices on learner autonomy between the teachers teaching at private schools and community schools is moderate. Likewise, regarding teachers' level, the tvalue is -0.70 , the degree of freedom (df) is 131 , and the significance level is 0.50 which is $(p>0.05)$. It suggests no statistically significant difference in practices on learner autonomy between teachers teaching at the basic and secondary levels.

Moreover, the calculated value of Cohen's $d$ is 0.12 , which signifies the weak effect in the difference. Here, it can be concluded that the difference in practices on learner autonomy between the teachers teaching at the primary level and secondary level is weak. In a similar vein, regarding the qualification of teachers, the t-value is -3.41 , degree of freedom ( $\mathrm{df}$ ) is 131 and significance level is 0.001 , which is $(\mathrm{p}<0.05)$. It suggests a statistically significant difference in learner autonomy practices between teachers having bachelor's and master's qualifications. Moreover, the calculated value of Cohen's $d$ is 0.62 , which signifies the moderate effect in the difference. Here, it can be concluded that the difference in practices on learner autonomy between the teachers having bachelor's and master's qualifications is moderate.

\section{Discussion}

This study displayed that English language teachers have good knowledge of learner autonomy. Most of them are aware of the basic concepts of learner autonomy. "Teachers cannot promote learner autonomy if they are unaware of it" (Neupane, 2010), and for them, learner autonomy means the situation where the students can make choices on how they learn. Learners make decisions on what and how to learn. It means if the learners cannot make decisions, "they can never be successful in learning new things" (Yagcioglu, 2015, p. 428). Nevertheless, it does not mean that there is no role of teachers in promoting learner autonomy. Foreign language teachers have a responsibility to foster learner autonomy (Benson, 2011).

Though teachers do not have traditional roles in traditional classes, teachers have essential roles in supporting learner autonomy, as this study's respondents agreed. Their role is to guide, facilitate and manage both students and resources. This finding is similar to the finding made by Joshi (2011) and Borg and Alshumaimeri (2019). It means the concept of learner autonomy has changed the role of teachers from authoritative to the facilitator, counsellor and manager. Voller (1997, as cited in Asmari, 2013) identifies three roles for teachers willing to work on an autonomous 
pedagogy: the teacher as facilitator, the teacher as a counsellor, and the teacher as a resource. The teacher is responsible for presenting his/her learners with the demands outlined in the curricular guidelines for their learning, within which they can set their own goals (Dam, 2011). As the findings of this study suggest, teachers perceive a positive role of learner autonomy in language learning. Learner autonomy facilitates second/foreign language learning. If students are autonomous, they learn a language on their own effectively. Zhang and Li (2004) pointed out that autonomous learners achieve high scores in a language test. It shows that learner autonomy is a significant factor for the development of language proficiency.

Several things promote learner autonomy, as the respondents of this study agreed. The teachers are aware that motivation, self-access centres like library/ internet and cooperation and collaboration among the students promote learner autonomy. This finding is similar to the finding made by Borg and Alshumaimeri (2019) and Borg and Al-Busaidi (2012). "Motivation is essential for affecting the manifestation of learner autonomy" (Bozkurt \& Arslan, 2018; p.120) both in and outside the classroom. Chan, Spratt and Humphreys (2002) support this idea by claiming that higher motivation levels enable learners to participate more in autonomous learning activities outside the classroom.

Moreover, teachers perceive that regular opportunities for completing different tasks independently and the tasks done outside the classroom help promote learner autonomy. It is the teachers' responsibility to create conditions for learners, where they can work on their own and teachers, need to monitor their tasks (Neupane, 2010). Evaluating the tasks done by the students independently, the teachers have to provide feedback to the students. To sum up, English teachers are aware of what learner autonomy is, why and how they have to promote learner autonomy.

As the English language teachers are aware of the what, why and how of learner autonomy, they provide tasks and opportunities which promote learner autonomy in their classroom. In other words, they encourage and motivate students to be involved in learner-centred tasks. As this study showed, teachers sometimes provide all necessary support to promote learner autonomy, whereas they always give students a chance to make decisions on their learning. Students are always encouraged to read extra materials/texts and use the library and internet to learn. This finding is similar to the finding made by Xhaferi and Xhaferi (2011). Likewise, the use of the internet and library sources promotes learner autonomy. Teachers always encourage students to learn collaboratively, be involved in outside classroom tasks and have selfcorrection/ peer correction of their errors, whereas they sometimes assign the task challenging in nature and encourage students to complete independently.

Teachers make students study the subject matter on their own before they come to the class and promote learning autonomy. English teachers' tasks in their English class reveal that they practice learner autonomy as they have perceived it. It means their perception of learner autonomy matched with their practice. The teachers should always provide all necessary support and assign challenging tasks to the students to promote learner autonomy since they have been doing these tasks sometimes. From the findings of this study, what can be concluded is English language teachers encourage their students to do tasks that promote learner autonomy on the one hand, and they use such tasks and activities in their classroom on the other.

The bivariate analysis showed that English language teachers' perceptions on learner autonomy do not differ by their sex (male and female), level in which they teach (primary and secondary), type of their school (private and community) and qualification of the teachers (bachelors and masters) and the difference found is weak. It means teachers, irrespective of their sex, level, type of their school, and qualification, perceive learner autonomy, and no other aspects of teachers affect their perceptions. Similarly, English language teachers' practices on learner autonomy do not differ by the sex and level of the respondents and the difference found is weak, but practices on learner autonomy differ by type of school where they teach, and their qualification and the difference found was moderate. It means teachers, irrespective of their sex and level, practice learner autonomy but the type of school they teach and their qualification affect their practices on learner autonomy.

\section{Conclusion}

Due to the paradigm shift in English language teaching approaches and methods, several changes can be seen in our English language class in terms of pedagogy, the role of teachers and students, and technology use. The shift has forced English language teachers to change their traditional role to facilitator and students to take charge of their learning. It means students should be autonomous enough to learn the English language on their own. Teachers' role is to provide students with opportunities to be involved in the tasks that promote learner autonomy. Learner autonomy is based on the principle that learning can happen if only learners are willing to learn themselves. There is a well-known proverb,' we can lead a horse to water, but we cannot make it drink'. As the essence of 
this proverb suggests, it is teachers' job to provide favourable situations, and some input promotes learner autonomy, and students have to make all the necessary efforts to learn independently.

Promoting learner autonomy in the Nepalese context may be difficult for the teachers in the initial days due to several teachers' constraints both in and outside the classroom. Nevertheless, it can be made possible with the efforts of all the stakeholders of education. First and foremost, the curriculum should be designed as per the principle of learner autonomy. Similarly, teachers should be given a certain level of autonomy in the selection of pedagogy and content. Though this study showed that English language teachers practice learner autonomy as its essence, teachers should be provided training pieces that help them be updated with recent trends and solve the challenges they face in promoting learner autonomy. Moreover, learners should be given a chance to decide on their learning, but teachers should scaffold and monitor them.

\section{References}

Asmari, A. A. (2013). Practices and prospects of learner autonomy: Teachers' perceptions. English Language Teaching, 6(3), 1-10. doi:10.5539/elt.v6n3p1

Balçıkanlı, C. (2010). Learner autonomy in language learning: Student teachers' beliefs. Australian Journal of Teacher Education, 35(1) 90- 103. http://dx.doi.org/10.14221/ajte.2010v35n1.8

Benson, P. (2011). Teaching and researching autonomy (2nd ed.). London: Pearson Education.

Benson, P., \& Voller, P. (1997). Autonomy and independence in language learning. London: Longman.

Borg, S., \& Al-Busaidi, S. (2012). Learner autonomy: English language teachers' beliefs and practices. London: British Council.

Borg, S., \& Alshumaimeri, Y. (2019). Language learner autonomy in a tertiary context: Teachers' beliefs and practices. Teaching Research, 23(1), 9-38. doi: 10.1177/1362168817725759

Bozkurt, N. \& Arslan, F. Y. (2018). Learner autonomy in language learning: Syrian refugee EFL learners' perceptions and readiness. Multidisciplinary Journal of Educational Research, 8(2), 115- 145. doi: 10.17583/remie.2018.3028

Chan, V., Spratt, M., \& Humphreys, G. (2002). Autonomous language learning: Hong Kong tertiary students' attitudes and behaviors.
Evaluation \& Research in Education, 16(1), 1-18. doi.10.1080/09500790208667003

Dam, L. (2011). Developing learner autonomy with school kids: Principles, practices, results. In D. Gardner (Ed.). Fostering Autonomy in Language Learning (pp. 40-51). Gaziantep: Zirve University. Retrieved from http://ilac2010.zirve.edu.trLeni Dam

Dickinson, L. (1987). Self-Instruction in language learning. Cambridge: Cambridge University Press.

Joshi, K.R. (2011). Learner perceptions and teacher beliefs about learner autonomy in language learning. Journal of NELTA, 16(1-2), 13-29.

Kumaravadivelu, B. (1994). The postmethod condition:(E) merging strategies for second/foreign language teaching. TESOL quarterly, 28(1), 27-48.

Little, D. (1995). Learning as dialogue: The dependence of teacher autonomy on learner autonomy. System, 23(2), 175-181.

Najeeb, S. S. R. ( 2013). Learner autonomy in language learning. Procedia - Social and Behavioral Sciences, 70, 1238 - 1242. doi: 10.1016/j.sbspro.2013.01.183

Nakata, Y. (2011). Teachers' readiness for promoting learner autonomy: A study of Japanese EFL high school teachers. Teaching and Teacher Education, 27(5), 900-910.

Neupane, M. (2010). Learner autonomy: Concept and considerations. Journal of NELTA, 15(1-2). 114120.

Reinders, H., \& Lazaro, N. (2011). Beliefs, identity and motivation in implementing autonomy: The teachers' perspective. In G. Murray, X. Gao, \& T. Lamb (Eds.), Identity, motivation, and autonomy in language learning (pp. 125-142). Bristol: Multilingual Matters.

Xhaferi, B., \& Xhaferi, G. (2011). Developing learner autonomy in higher education in Macedonia. Procedia Social and Behavioral Sciences, 11, 150154. doi:10.1016/j.sbspro.2011.01.051

Yagcioglua, O. (2015). New approaches on learner autonomy in language learning. Procedia - Social and Behavioral Sciences, 199, 428 - 435. doi: 10.1016/j.sbspro.2015.07.529

Zhang, L.X., \& Li, X.X. (2004). A comparative study on learner autonomy between Chinese students and west European students. Foreign Language World, 4, 15-23. 